Uluslararası Ekonomi ve Yenilik Dergisi, 1 (1) 2015, 31-54

\title{
Girişimciler İçin Alternatif Finansman Kaynakları: Mevcut Durum ve Öneriler
}

\author{
Bünyamin $\mathrm{ER}^{1}$ \\ Yunus Emre ŞAHIN ${ }^{2}$ \\ Mesut MUTLU ${ }^{3}$
}

ÖZ: Ithalata dayalı büyüme anlayışı yerine ar-ge ve inovasyona dayalı büyüme anlayışına geçiş ile birlikte girişimcilik öncesine göre daha önemsenir bir konuma ulaştı. Her ne kadar girişimcilik kültürel gelişimin bir parçası olarak ifade edilse de henüz bu yönde yeterli mesafe alınamadĭ̆ ifade edilmektedir. Girişimciliğin bu anlamda gelişmesinin önündeki en büyük engellerden birisi olarak ise finansal kaynakların yetersizliği ve/veya mevcut finansal kaynaklara erişim zorlukları öne çıkmaktadır. Finansman kaynaklarına erişim noktasında alternatif finansman kaynaklart girişimciliğin gelişmesi açısından bir firsat penceresi olarak dĕgerlendirilebilir. Bu yönde hem mevcut alternatif kaynakların geliştirilmesi ve hem de yeni alternatif kaynakların girişimcilerin kullanımına sunulması gerekmektedir. Bu çalışmada, girişimciliğin geleneksel ve alternatif finansal kaynaklart değerlendirilerek, alternatif finansal kaynakların daha etkin kullandırılması yönünde öneriler sunulmuştur.

Anahtar Kelimeler: Girişim sermayesi, Melek yatırım, İslam bankacılığg

JEL Kodları: G21, G24, L26

\section{Alternative Sources of Financing for Entrepreneurs: Present Situation and Recommendations}

ABSTRACT: Entrepreneurship has reached a better position than before along with transition to growth based on innovation and $R \& D$ rather than import-orient growth. Much as entrepreneurship is stated as part of cultural growth, yet is stated to not progress enough in this direction. In this context, one of the biggest obstacles to development of entrepreneurship is the lack of financial resources and/or access restrictions financial resources. Alternative financing sources on the access point to financial resources are evaluated as a window of opportunity for the development of entrepreneurship. In this context, both are enhanced the alternative current resources and be should available to entrepreneurs new alternative resources. In this study, traditional and alternative financial resources of entrepreneurship have been evaluated and given suggestions to make use of alternative financial resources effectively.

Keywords: Venture capital, Angel investment, Islamic banking

JEL Codes: G21, G24, L26

\footnotetext{
${ }^{1}$ Doç.Dr., KTÜ İİBF İşletme Bölümü, ber@ktu.edu.tr

${ }^{2}$ Yüksek Lisans Öğrencisi, KTÜ SBE Finans YL Programı, ynseshn@gmail.com

${ }^{3}$ Yüksek Lisans Öğrencisi, KTÜ SBE Finans YL Programı, mesut.mutlu@ outlook.com
} 
1. Giriş Yerine: Girişimcilik ve Girişimciliğin Finansmanında Geleneksel Yöntemler

Girişimcilik; yeni pazar, ürün ve/veya süreç fırsatlarını tespit ederek, bu firsatlardan faydalanmak amacıyla bir iktisadi faaliyetin başlatılması veya genişletilmesi yönündeki çaba olarak tanımlanabilir. Bir olgu olarak bu şekilde tanımlanabilecek girişimcilik kavramı içinde girişimci, en yalın bir şekilde, yukarıda bahsedilen çabayı gösteren kişidir.

Klasik anlamda girişimci, üretim faktörlerini organize ederek üretim faaliyetinde bulunan ve üstlendiği riskle birlikte sonuçta kâr elde etmeyi amaçlayan kişi olarak tanımlanmaktadır. Bununla birlikte son yıllarda girişimciliğin tanımına "yeni veya farklı bir şeyler yapma ve topluma değer katma" (Kao, 1993: 69) unsurları da eklenmiştir. Girişimciliğin önemi, girişimcilerin toplumun ihtiyaçlarını belirleyip, bunu yatırıma, sonunda da toplumsal refaha dönüştürmelerinde yatmaktadır (Kızılgöl, 2008: 3).

Girişimcilik özellikle son yıllarda bölgesel ve ulusal kalkınmanın en büyük itici gücü olarak değerlendirilmektedir. Ülkeler açısından işsizliği azaltması ve ekonomik büyümeye katkı sağlaması dolayısıyla önemli bir değer olarak nitelendirilen girişimcilik, her yönüyle toplumsal fayda sağlamanın ötesinde yeni fikirlerin yol bularak yeni iş alanlarının oluşmasına neden olmaktadır (İbicioğlu, 2010: 54). Dolayısıyla girişimciliğin kültür haline getirildiği ve girişimcilik bilincinin geliştirildiği ülkelerin işveren sayısında, üretiminde ve ekonomisinde önemli ölçüde büyüme ve gelişme söz konusu olmaktadır (Uluköy, 2013: 80).

Finansman ise, bir işletmenin yatırımlarını ve devam eden finanse etmek için ihtiyacı olan para veya sermayenin sağlanmasıdır. İşletmeler ihtiyaç duydukları fonları iç kaynaklarından karşılayabildikleri gibi işletme dışı çeşitli kaynaklardan da temin edebilmektedirler. Öz kaynaklar olarak da ifade edilen iç kaynaklar, işletme sahibinin ve ortaklarının mal varlığı ile faaliyet kârından oluşmaktadır. İşletmeler özellikle kurulma aşamasında, diğer finansman kaynaklarına ulaşma konusunda yaşadıkları sıkıntıların da etkisiyle, kendi öz sermayelerini kullanırken büyüme ve gelişme evrelerinde çoğunlukla bu kaynaklar yeterli gelmemekte dışarıdan finansmana ihtiyaç duymaktadırlar. Banka kredileri, finansal kiralama (leasing), faktoring, girişim sermayesi, yurtiçi ve yurtdışı finansal kurumlar ile sermaye piyasalarından sağlanan çeşitli krediler şeklinde ifade edilebilen işletme dışı kaynaklar ise işletme içi kaynaklara göre daha çeşitli olabilmektedir. $\mathrm{Bu}$ kaynakların bir kısmından işletmeler borçlanma yoluyla fon sağlarken diğer kısmından sermaye artırımı şeklinde kaynak temin etmektedir.

Yeni kurulan girişimlerin finansman gereksinimleri, biçimsel ve biçimsel olmayan olmak üzere iki şekilde sağlanmaktadır. Biçimsel kaynaklar; bankalar, devlet, kredi kuruluşları, girişim sermayesi fonları vb. iken, biçimsel olmayan kaynaklar ise kişisel tasarruflar, aile ve arkadaşlar ile melek yatırımcılardan oluşur. Yeni kurulan girişimlerin finansmanında biçimsel olmayan kaynaklardan, melek 
yatırımcıların önemi gün geçtikçe artmakta ve girişimcilik literatüründe her geçen gün daha fazla incelenmektedir (Karabayır ve diğerler, 2012: 70). Dolayısıyla girişimcinin finansman zinciri, aile, eş ve dostlardan elde edilen mali destekle başlayıp, hibeler, tohum sermayesi, iş melekleri, girişim sermayesi, KOBİ kredileri, halka arz ile devam eden geniş bir yelpazeye yayılmaktadır.

Girişimciler işlerini temelde öz sermayeleri veya eş ve çevrelerinden elde ettikleri sermaye ile kurarlar (tohum evresi yatırımları). Yazında melek yatırımcı, Türkiye'de ise Bireysel Katılım Sermayedarı olarak bilinen yatırımcılar erken evre girişimcilere destek olurlar (www.oecd.org). Girişim sermayesi fonlarıysa daha çok girişimin daha sonraki evrelerinde rol alan bir finansman aracıdır. Ancak sermaye finansmanı olarak bilinen bu yöntemlere ek olarak ve aslında çok daha sık olarak kullanılan finansman aracı ise temel borçlanma finansmanı olarak ifade edilen banka kredileridir. Dolayısıyla, öz sermaye her ne kadar önemli bir unsur olsa da bir girişimi başlatmak ve daha da önemlisi büyütmek için çoğu zaman yeterli olmamaktadır. Birçok girişimcinin dış finansman kullanmadan, girişimini belirli bir noktaya getirmesi oldukça güçtür. $\mathrm{Bu}$ nedenle, girişimcilik ekosisteminin kalitesini belirlemek açısından finansman kaynaklarının çeşitliliği, ulaşılabilirliği ve koşulları oldukça önemli unsurlardır.

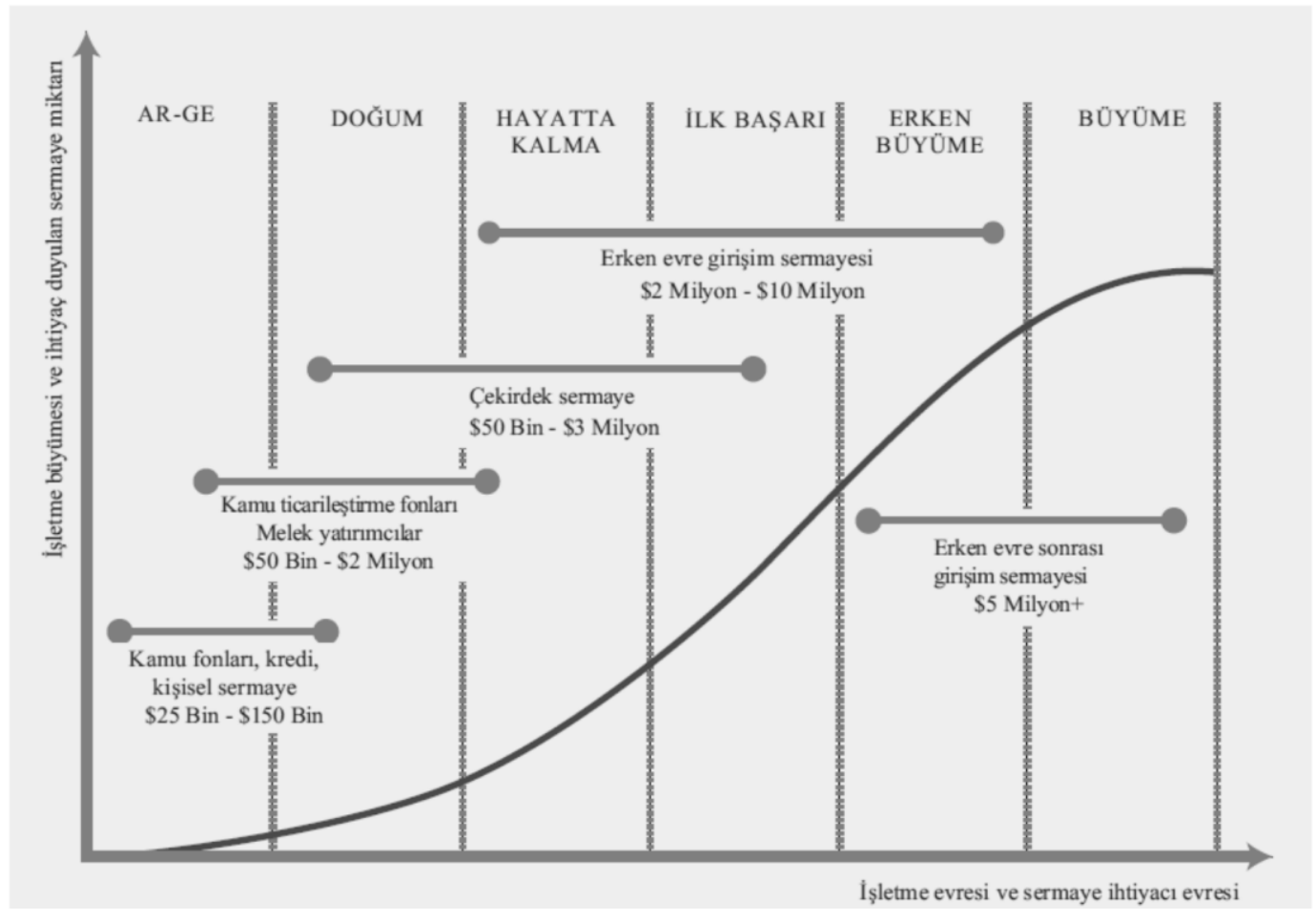

Şekil 1: Girişim Evreleri ve Finansman İhtiyaçları

Kaynak: Kalkınma Bakanlı̆̆ $, 2014: 9$ 
Türkiye'de girişimcilerin finansal kaynaklara erişimi genellikle serbest piyasa ve kamu kaynakları olmak üzere iki kanaldan gerçekleşmektedir. Serbest piyasa açısından bakıldığında bankacılık sistemi en önemli finansal kaynak sağlayıcısı konumundadır. Bankacılık sistemi dışında özel girişim sermayesi firmaları da girişimciler için önemli bir finansal kaynak sağlayıcısı olarak değerlendirilebilir.

Kamu kaynaklarıyla sağlanan devlet yardımlarının bir kısmı faaliyet desteği (girişimci ve KOBİ'lerin yapacakları faaliyetlere destek), diğer bir kısmı ise sermaye desteği (kredi garantisi, kredi faiz desteği vb.) şeklindedir. Diğer taraftan, farklı bakanlıklarca işletmelere ve yatırımcılara sağlanan teşvikler (vergi, sosyal güvenlik primi vb.) de bulunmaktadır. Ayrıca; kamu, IŞGEM ve TEKMER tipindeki yapıların kuruluş ve işletmesine yaptığı nakdi/ayni katkılarla da girişimcilere dolaylı destekler sağlamaktadır. Dolayısıyla, girişimci ve KOBİ'lere kamu kaynaklarıyla sağlanan doğrudan ve dolaylı mali destekler çok büyük bir çeşitlilik göstermektedir (Kalkınma Bakanlığı, 2014: 32).

Kamu kaynaklı destekler içerisinde KOSGEB tarafından sağlanan kredi faiz desteği, Bilim, Sanayi ve Teknoloji Bakanlığı tarafından yeni ve yenilikçi girişimleri desteklemek amacıyla kullandırılan Teknogirişim Sermayesi Desteği, yine KOSGEB tarafından kullandırılan Yeni Girişimci Desteği şeklinde sermaye destekleri ve Bilim, Sanayi ve Teknoloji Bakanlığı, Ekonomi Bakanlığı, TÜBITAK, KOSGEB, TTGV, Kalkınma Ajansları vb. kurumlar tarafindan kullandırılan faaliyet destekleri yer almaktadır (Kalkınma Bakanlığı, 2014: 32-35)

Çoğu ülkede olduğu gibi Türkiye'de de bankalar, KOBİ'lerin en önemli finansman kaynağı durumundadır. Küçük işletmelerin banka kredilerine erişimde, büyük işletmelere kıyasla daha fazla sorun yaşamaları nedeniyle bu işletmelerin krediye erişimlerinin artırılmasına yönelik olarak kamu tarafından çeşitli destek programları uygulanmaktadır. Bu destekler, politika öncelikleri doğrultusunda uygun koşullu (düşük faizli, uzun vadeli gibi) kredi programları yürütme, kredi garanti sistemleri ve mikro kredi sistemleri oluşturma gibi farklı biçimlerde olabilmektedir. Son y1llarda gelişmiş ülkeler, kredi garanti sistemleri geliştirme, makroekonomik ve finansal sisteme yönelik iyileştirmeler yapma gibi piyasaya daha az müdahaleci politikaları tercih etmektedirler (Yüksel, 2011: 2).

KOBİ'lerin ölçeklerine ve bulundukları iş ortamına bağlı olarak banka kredilerine erişimde yaşadıkları sıkıntıların niteliği ve boyutu da farklılık göstermektedir. Küçük ve genç işletmeler genellikle her koşulda krediye erişimde ve kredi maliyetinde sorun yaşarken; orta ölçekli işletmeler gelişmiş ülkelerde kredi hacminin yetersizliği ve koşulların uygun olmaması, gelişmekte olan ekonomilerde ise krediye erişim konularında sıkıntı yaşayabilmektedir. Bu durum, genellikle gelişmekte olan ülkelerde finansal sistemin daha az gelişmiş olması, likidite azlığ $\breve{v}_{1}$ e bankaların küçük ölçekli işletmeleri kredilendirme konusunda tecrübesiz ve isteksiz olmasından kaynaklanmaktadır. Son yıllarda KOBİ kredileri konusunda bankacılık sisteminde uzmanlaşma yönlü bir gelişme olmasına karşın durum yine de olması gereken noktanın uzağındadır. 
Uygun koşullu finansmana erişimde yaşanan sıkıntılar, Türkiye'de KOBİ'lerin kurulma ve büyümeleri önünde de önemli bir engel oluşturmaktadır. Gelişmiş ve benzer gelişmişlik seviyesindeki ülkelerin birçoğuna kıyasla Türkiye'de işletmelere sağlanan bankacılık sektörü kredileri daha düşük seviyede olmasının yanında, kredi faiz oranları da bu ülkelerle karşılaştırıldığında daha yüksektir. Bunların yanı sıra Türkiye'de KOBİ'lerin büyük bir kısmının mikro ölçekli, mali ve kurumsal yapısı zayıf işletmeler olması da krediye erişimlerini zorlaştıran önemli bir faktördür.

Türkiye'de KOBİ'ler, ağırlıklı olarak mikro ölçekli bir yapılanmaya sahip olup büyük bir kısmı aile işletmesi şeklinde faaliyet gösteren geleneksel yapıdaki işletmelerdir. $\mathrm{Bu}$ işletmelerde genellikle işletme sahibi ile yöneticisi aynı kişi olmakta veya işletme sahipleri çok yakın aile bireylerinden oluşmaktadır. Dolayısıyla bu tür işletmelerde alınan tüm kararlar bir kişiye veya gruba bağlı olmakta ve kişinin/kişilerin bilgi, beceri ve yönetim kapasitesi işletmelerin performansında belirgin bir role sahip olmaktadır. Bu işletmeler, kurumsallaşma düzeylerinin düşük olmasının yanı sıra insan kaynakları, finansal yönetim, pazarlama ve yeni ürün ve hizmet geliştirme gibi konularda da sıkıntılar yaşamaktadırlar. Bu veriler esasında Türkiye'deki KOBİ'lerin finansman yanında kurumsallaşma problemlerinin olduğunu da göstermektedir. Dolayısıyla, finansman desteğinin yanında yönetim ve organizasyon anlamında da destek sağlayan ve bu anlamda katılımcı finansman yöntemleri olarak da ifade edilebilecek olan girişim sermayesi ve melek yatırım finansman modelleri Türkiye'deki KOBİ'ler için önemli birer fırsat alanı olarak değerlendirilebilir.

Grafik 1: KOBİ Kredilerinin Toplam Krediler İçerisindeki Payı

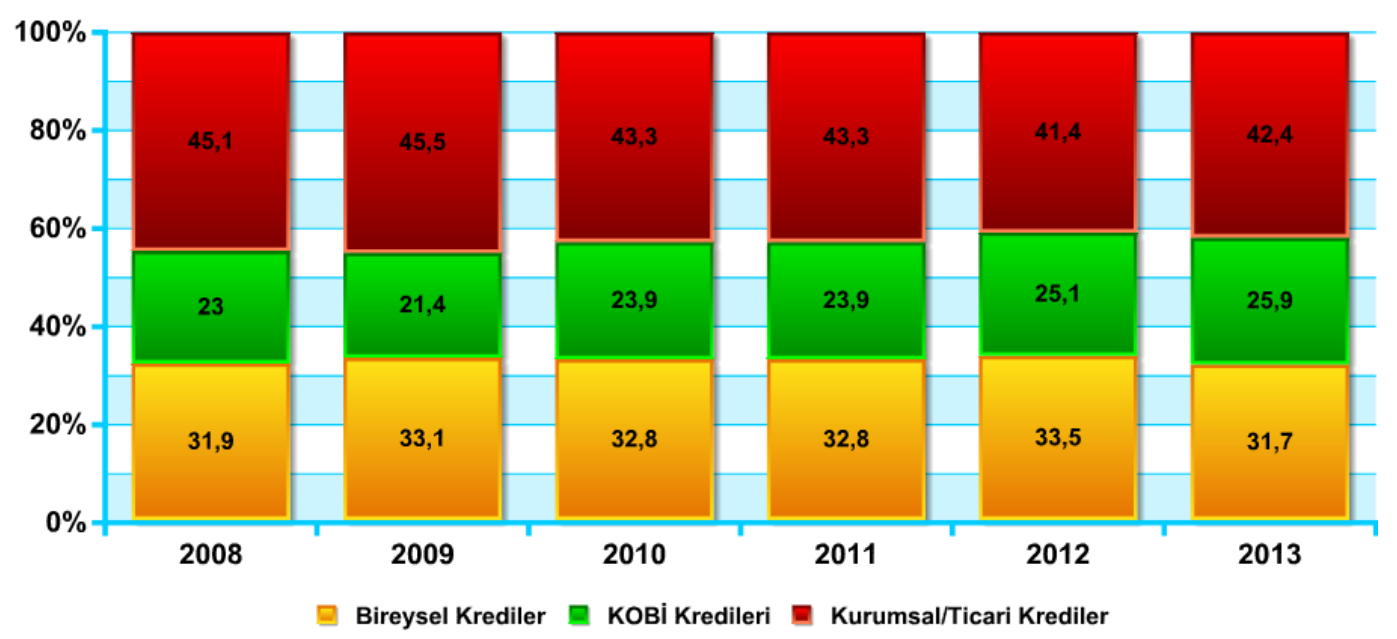

Kaynak: Bankacılık Düzenleme ve Denetleme Kurumu (BDDK)

Grafik 1'de de görüldügü gibi Türkiye'de toplam banka kredileri içerisinde KOBİ kredilerinin aldığı pay oldukça düşüktür. Küçük işletmeler bu nedenle ekonominin 
başka kanalları aracılığıyla kendilerine kaynak aramak zorunda kalmakta ve çoğu zaman da yeni ve büyüyen işlerinin ihtiyaçlarını karşılayabilecek yeterli kaynağı bulamamaktadir.

Grafik 2: KOBİ Kredilerinin İşletme Ölçeğine Göre Dağılımı

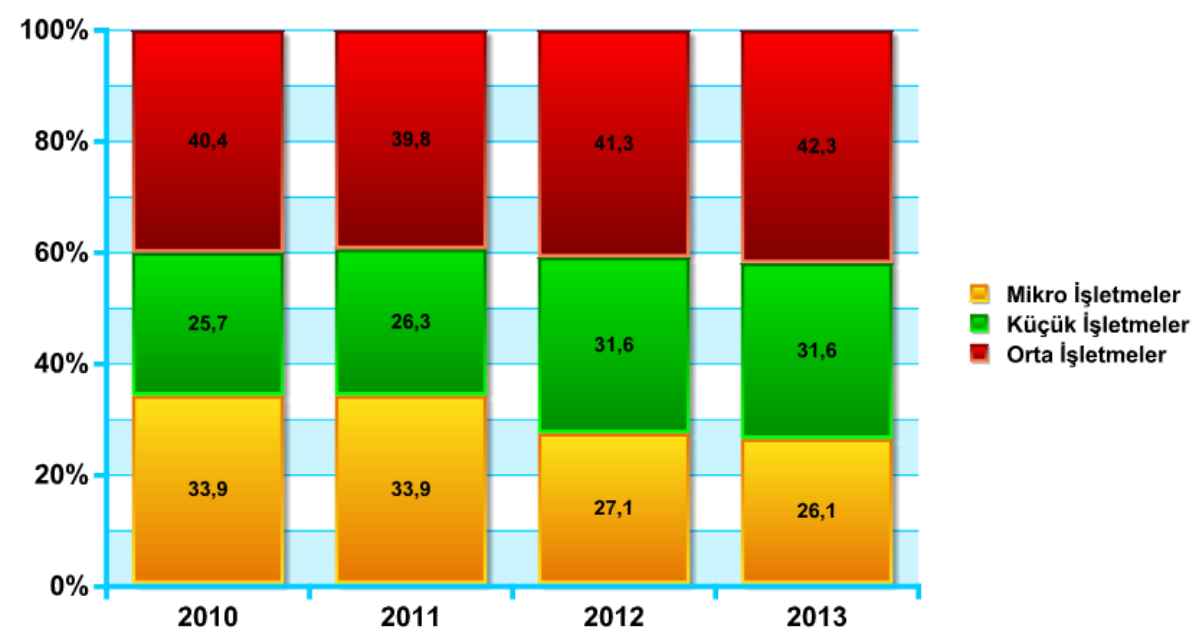

Kaynak: BDDK

Türkiye'de bankacılık kesiminin kullandırdığı toplam krediler içerisinde KOBİ kredilerinin payına bakıldığında bunun ortalama olarak \% 25 düzeyinde olduğu görülmektedir (Grafik 1). $\mathrm{Bu}$ oran ekonomiye katkıları açısından değerlendirildiğinde KOBİ'ler için oldukça düşüktür. Zira bu oran, gelişmiş ülkelerde $\%$ 50'lerin üzerindedir. $\mathrm{Bu}$ durum krediye erişim ve kredi koşulları bakımından Türkiye'deki KOBİ'lerin, gelişmiş ve benzer gelir düzeyindeki ülkelerin birçoğuna kıyasla daha fazla sorun yaşadığını göstermektedir. Mikro işletmeler, yeni girişimciler, yenilikçi ve hızlı büyüme potansiyeli olan riskli işletmeler, yeterli teminatı olmayan işletmeler ile gelişmişlik seviyesi düşük bölgelerdeki işletmeler krediye erişim bakımından en fazla sorun yaşayan kesimlerdir. Zira banka kredileri içerisinde bireysel ve ticari/kurumsal kredilere göre daha az paya sahip olan KOBİ kredilerinin dağılımına bakıldığında (Grafik 2), özellikle son yıllarda mikro ölçekli KOBİ'lerin KOBİ kredileri içerisindeki payının küçük ve orta işletmelere göre azaldığı görülmektedir.

\section{Girișimcilerin Finansmanında Alternatif Yöntemler}

\subsection{Girişim Sermayesi (Risk Sermayesi)}

Girişim sermayesi genel olarak; dinamik, yaratıcı ve önemli ekonomik değerler üretme potansiyeli olan ancak finansal gücü yeterli olmayan genç ve hılı büyüyen firmaların yatırım fikirlerini gerçekleştirmeye olanak tanıyan bir yatırım finansman biçimi olarak tanımlanabilir. Girişim sermayesinin temelinde yeni oluşum ya da küçük şirket vardır. Sermayedar için, fikrin başlangıç aşamasında, 
ürün ortada yokken ve pazarda satılabilirliği ya da kabul görmesi kanıtlanmamış, denenmemiş iken ortak olmak, getiriyi arttırmaktadır. Diğer taraftan girişimci de ortaya koymak istediği ürün ya da hizmeti sermaye yetersizliği nedeniyle deneyemez iken girişim sermayesi sayesinde şirketine sermaye sağlayarak tasarladığ1 ürün ya da hizmetin satışı ile istediği büyüklüğe sahip olma şansını artırmaktadır.

Girişim sermayesi, öz kaynak yatırımıdır. Sermayedar, şirkete borç verme yoluyla finansman sağlamak yerine ortak olmaktadır. Sermayedar hisse senedi aracılı̆̆ıla şirkete ortak olduğu için yönetime katılma hakkı da elde etmiş olmaktadır. Girişim sermayesi yatırımında var olan risk ise; yeni bir ürün üretilmesi ve piyasada tutulması riskidir. Ancak, yüksek riskin yüksek getiriyi getireceğinden yola çıkan bu finansman modelinde; alınan riskin başarıya dönüşmesi durumunda sağlanacak yüksek kar marjı ve büyük satış hacminden kaynaklanan verimlilik artışı bu şirketlere ortak olmak suretiyle finansman sağlayan yatırımcıların faydasını oluşturur.

Girişim sermayesinin ilk uygulandiğı yer Amerika Birleşik Devletleri'dir. Amerikan girişim sermayesi şirketlerinin başarısı ile birlikte diğer ülkelerde de bu tür şirketlerin kurulması ve gelişmesi sağlanmıştır. Bu ülkeler arasında ön sıraları Japonya, İsrail ve başta İngiltere olmak üzere Avrupa ülkeleri almaktadır. Girişim sermayesi Amerika'da 1970'li yıllardan sonra tutar ve yatırım sayısı yönüyle çok önemli boyutlara varmış bir finansman yöntemidir. 2000 yılında yıllık toplam yatırım tutarı açısından rekor seviyesi olan 105 milyar dolara ulaşan girişim sermayesi yatırımları, 2000 yılından bu yana dalgalı bir seyir izlemişse de çoğu zaman artış trendinde olmuştur.

Avrupa'da ise, girişim sermayesine ilişkin faaliyetler özellikle 1980 yılından sonra hareketlenmiştir. Çeşitli çalışmalarda Avrupa Birliği'ne üye ülkelerin kendi düzenlemeleri ve ortak programlarla Avrupa'da girişim sermayesi yatırımlarının olumlu yönde ivme kazandığı belirtilmektedir. Avrupa Merkez Bankası'nın 20072012 yıllarını baz alarak yaptığı çalışmada 2008 yılından sonra girişim sermayesi yatırımlarının azalma trendinde olduğu gösterilmiştir. Bunun çeşitli sebepleri olmakla birlikte en büyük sebebinin Amerika Birleşik Devletleri'nde 2007 yılında başlayıp 2008 yılında uluslararası piyasalara yayılan ve 2009 yılından sonra da etki boyutunu arttıran ekonomik kriz olduğu ifade edilmektedir. 2013 yılında Avrupa'da girişim sermayesi yatırımının toplam miktarı 2012 yılına göre \%5 artarak 3,4 milyar Euro'ya yükseldi. Söz konusu yılda 3000'den daha fazla şirkete girişim sermayesi desteği sağland. 
Grafik 3: Dünya'da ve Avrupa'da Girişim Sermayesi Yatırımları (milyar \$) ve Sözleşme Sayıları (bin Adet)

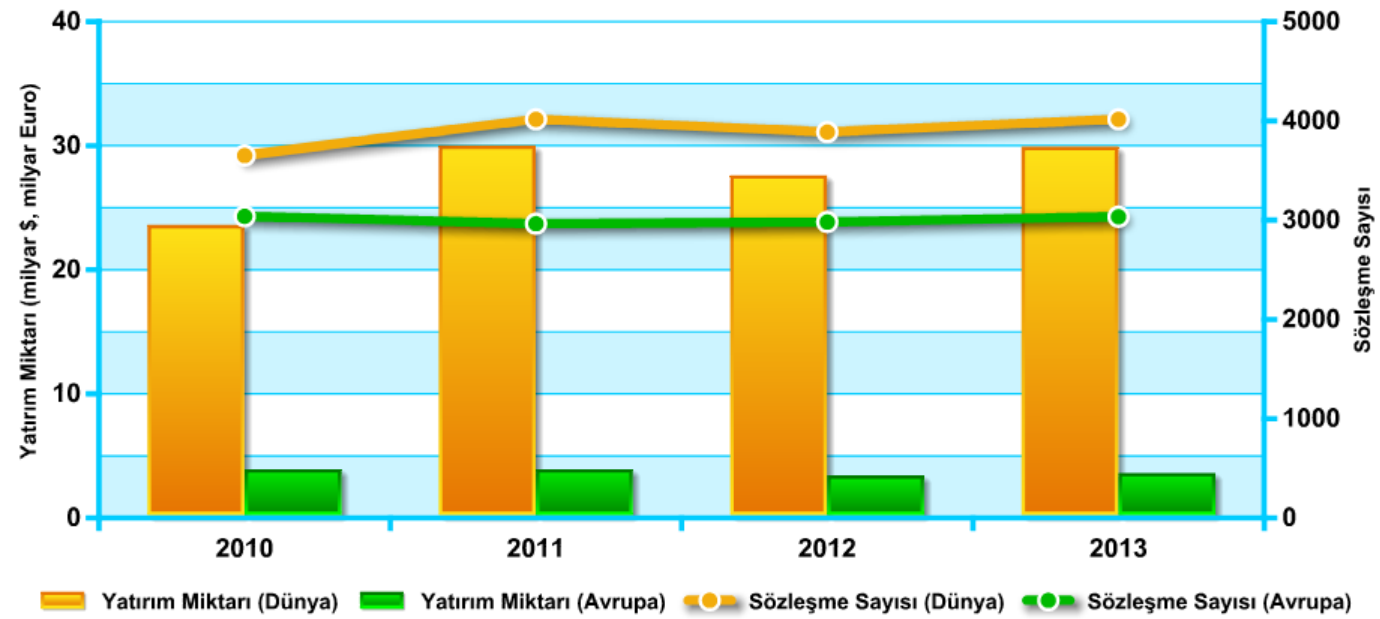

Kaynak: Pricewaterhouse Coopers, EVCA

Türkiye'de ise girişim sermayesi uzun yıllar uygulama imkanı bulamamıştır. Gerek yerli sermayenin yetersizliği, gerek bilgi eksikliği, gerekse yasal düzenlemelerin yeterli olmayışı ilgiyi bu noktadan uzaklaştırmıştır. 1990'lı yılların ortalarından sonra özellikle Sermaye Piyasası Kurulu'nun düzenlemeleriyle harekete geçilmiş, yurt dışı kaynaklı fonların da faaliyet göstermeye başlamasıyla girişim sermayesi Türkiye'de ilgi görmeye başlamıştır. Ancak Türkiye'de girişim sermayesi, 2000'li yılların başına kadar pek fazla gelişme gösterememiş, yaygın olarak kullanılan bir finansman çeşidi olarak değerlendirilmemiştir. Girişim sermayesinin Türkiye'de uzun yıllar gelişememesinin çok çeşitli sebepleri olmakla birlikte, üzerinde en çok durulan nokta Türkiye ekonomisinin durgun yapısının girişim sermayesi yatırımlarını sınırlandırmıș olmasıdır. Bu bağlamda girișim sermayesinin uzun vadeli bir finansman aracı modeli olması ve gelișimi için sağlıklı ve istikrarlı bir ekonomik yapıya ihtiyaç duyması önemli etkenler olarak ifade edilmektedir.

Girişim sermayesi konusunda Türkiye'deki ilk girişim bankalar tarafından gerçekleştirilmiştir. Bu amaçla kurulan ilk fon Vakıf Risk A.Ş. olup, şu anda Türkiye'de 6'sı halka açık olmak üzere (www.kap.gov.tr) Sermaye Piyasası Kurulu (SPK)'ndan lisans almış toplam 12 adet (www.spk.gov.tr) girişim sermeyesi yatırım ortaklığı (GSYO) firması bulunmaktadır. 2013 yılı sonu itibari ile halka açık GSYO'ların portföy değerleri 541 milyon \$'a ulaşmıştır. Yukarıda da ifade edildiği gibi GSYO'lar farklı yatırım alternatiflerini içerisinde barındırırlar. $\mathrm{Bu}$ yatırım alternatifleri içerisinde girișim sermayesi yatırımlarının önemli bir ağırlık taşıdığı ve bu ağırlığın da yine son yıllarda artış gösterdiği görülmektedir. 2013 yılı verilerine göre GSYO'ların porföy değerleri içerisinde 
girişim sermayesi yatırımlarının ağırlığ $\%$ 77,15 olarak gerçekleşmiştir. $\mathrm{Bu}$ anlamda GSYO'ların portföy değerleri ve girişim sermayesi yatırımlarının portföy içerisindeki ağırlığının gelişimi Grafik 4'te gösterilmiştir.

Grafik 4: Türkiye'de Kurulu GSYO (Halka Açık)'ların Portföy Değerleri (milyon \$) ve Girişim Sermayesi Yatırımlarının Portföy İçerisindeki Payı (\%)

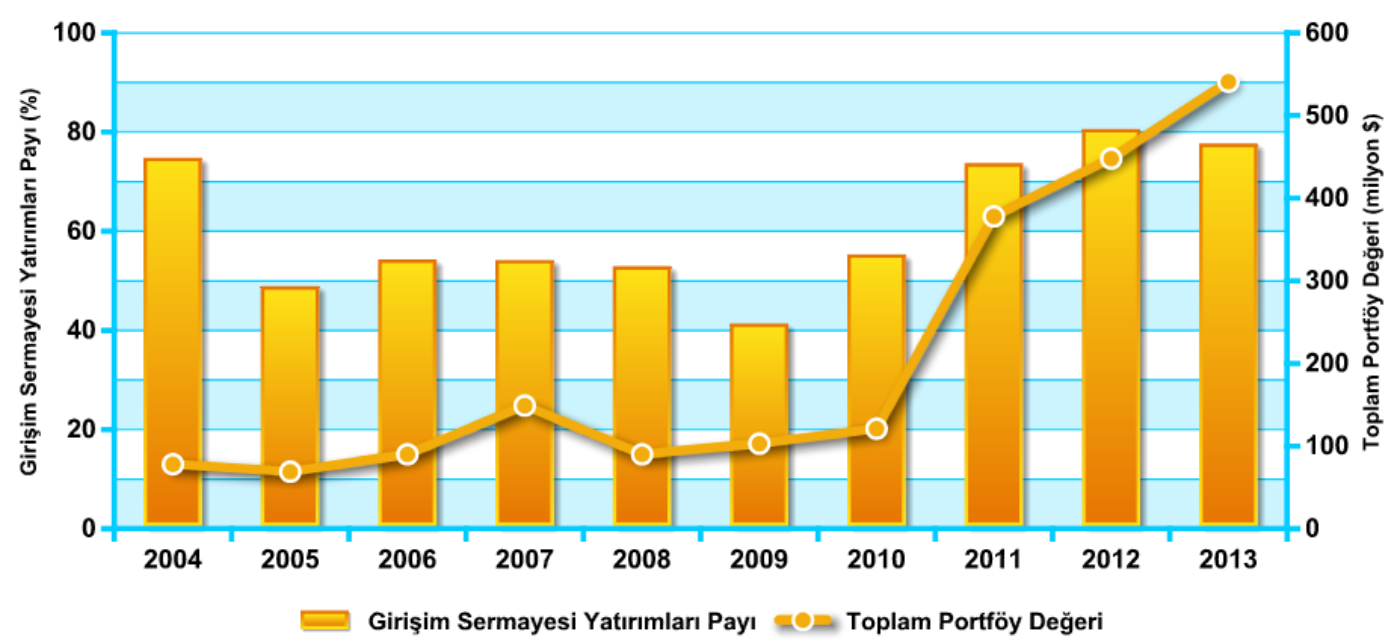

Kaynak: SPK

Türkiye'deki girişim sermayesi yatırım ortaklığı sistemi çekirdek, başlangıç ve yönetimin satın alınması aşamalarındaki projelere yatırım yapmamaktadır. Özellikle çekirdek aşamasındaki firmaların riski oldukça yüksek olduğundan bu firmalar ölüm vadisinde olarak nitelendirilmekte ve yatırım yapılmamaktadır. Türkiye'de genellikle fikir aşamasını geçmiş, firmasını kurmuş ve kar elde etmeye başlamış ancak büyümek, yatırımlarını devam ettirebilmek amacıyla finansmana ihtiyacı olan firmalara yatırım yapılmaktadır (www.yoikk.gov.tr).

\subsection{Melek Yatırım}

Melek yatırım kavramı ilk olarak Broadway'deki borsa tüccarlarının, Broadway gösterilerinin devam etmesi için riskli yatırım yapan zenginleri ifade etmede kullandıkları bir terimdir (Karabayır vd., 2012). Melek yatırımı tanımlamak adına öncelikle melek yatırımı oluşturan iki temel unsurdan bahsetmek gerekir. Bunlardan birincisi girişimci (entrepreneur), diğeri ise riski büyük ölçüde üstlenen, Türkiye'deki ilgili mevzuata göre Bireysel Katılım Yatırımcısı (BKY) olarak adlandırılan melek yatırımcı (angel investor)'dır.

Girişimciler, bir fikri bulan ve buna bağlı bir iş planı olan ve girişimini büyütmek için sermayeye ihtiyaç duyan kişiler olarak tanımlanabilir. Demirel ve Tikici (2004)'ye göre girişimciler; vizyon, misyon ve hırs olmak üzere üç anahtar özelliğe sahip olan, ileriye dönük düşünen, kendilerini motive eden, özgüveni 
bulunan, strese karşı dayanaklı, problemlere çözüm odaklı yaklaşan ve baskın bir bireysek karaktere sahip olan kişilerdir.

Melek yatırımcılar ise risk sermayesi kuruluşlarının yatırım yapamayacağı kadar erken evrede bulunan girişimlere, genellikle küçük miktarlarda (100.000 TL1.000.000 TL) finansman ve bu finansmanla birlikte girişimcilere satış, pazarlama, insan kaynağı tedariki ve eğitimi, yönetim gibi hususlarda destek olan varlıklı şahıslardır. Osnabrugge (2000) melek yatırımcıları, birçoğu önceden kendi işini kurmuş, servetlerini ve tecrübelerini yeni kurulan küçük girişimlere aktarmak isteyen bireysel yatırımcılar olarak tanımlamıştır. Türkiye'de ise Hazine Müsteşarlığı tarafından 15.02.2013 tarihinde Resmi Gazete'de yayımlanan Bireysel Katılım Sermayesi Hakkındaki Yönetmeliğe göre Bireysel Katılım Yatırımcıları; iki takvim yılı içerisinde yıllık geliri en az 200.000 TL veya menkul ve gayrimenkul varlıklarının toplamı 1.000.000 TL olan, son 5 yıl içerisinde en az iki yıl, y1llık cirosu 25.000.000 TL olan bir şirkette en az Genel Müdür Yardımcılığ 1 pozisyonunda çalışılması vb. tecrübe kriterlerini sağlayan, kişisel maddi varlık ve tecrübelerini başlangıç aşamasındaki şirketlere aktaran gerçek kişiler olarak tanımlanmıştır.

Grafik 5: Çeşitli Ülkelerde Melek ve Küvez (İnkübatör) Yatırımları (2013, milyar \$)

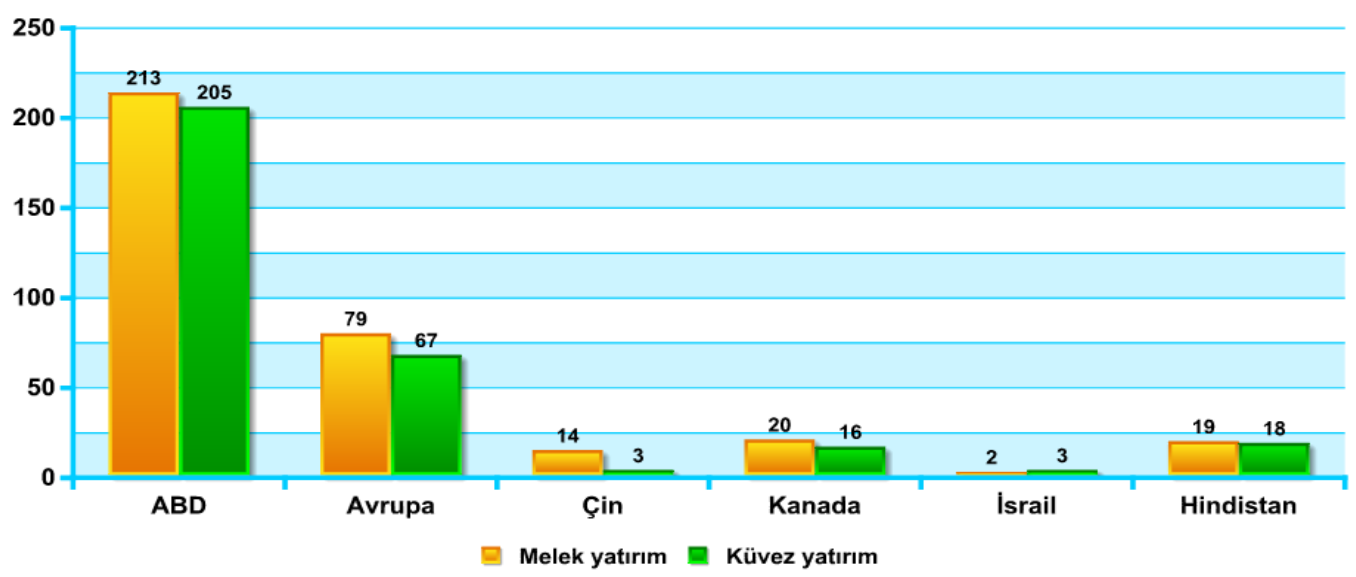

Kaynak: Ernst \& Young Global Limited

Dünyada yaklaşık 300 milyon kişi; yaklaşık 150 milyon yeni işe başlamayı denemektedir. Bunların her yıl yaklaşık 3'te 1'i yani 50 milyonu veya her gün yaklaşık 130 bini yeni bir firma olarak doğmaktadır. Bu firmaların çoğu başarısız olarak ortadan kalkmakta, bazıları ise başarılı olarak büyümektedir (Oduyoye vd., 2013). Girişimciler; girişimlerine finansman bulmak amaciyla banka, banka benzeri finansal kuruluşlara müracaatlarında fikirlerine yönelik yatırımın fazla risk taşıması, teminat yetersizlikleri gibi nedenlerden dolayı finansman elde 
edememektedir. Girişim sermayesi şirketlerinin veya özel sermaye fonlarının daha çok ileri aşamadaki şirketlere finansman sağlaması, erken evre girişim finansmanı konusunda boşluklar oluşturmuştur. İşte tam bu noktada melek yatırımcılar yeni fikir sahibi bireyler ve erken evre girişimler için önemli bir alternatif finans kaynağı olmuştur (www.oecd.org).

Melek yatırıma yönelik uygulamalar ABD'de yaklaşık 35 yıl öncesinde, Avrupa'da yaklaşık 25 yıl öncesinde başlamasına karşın Türkiye'de bu alternatif finans yöntemine yönelik uygulamaların geçmişi yaklaşık 10 y1l öncesine dayanmakta olup çok sınırlı sayıda uygulama gerçekleşmiştir. 2013 yılı sonu itibari ile ACA (Angel Capital Association) ve EBAN (European Trade Association for Business Angels, Seed Funds and other Early Stage Market Players)'den elde edilen verilere göre; ABD'de görünür ve görünmez melek yatırım piyasalarında 298.000 bireysel melek yatırımc1, 32.000'i çekirdek evre, 29.000'i başlangiç evresi ve 9.000'i büyüme evresinde olmak üzere toplam 71.000 melek yatırım anlaşmasına yaklaşık 25 Milyar \$'lık yatırım gerçekleştirmiştir. Avrupa'da ise 271.000 bireysel melek yatırımc1, 3.677'si fikir evresi, 7.355'i çekirdek evre, 18.053'ü başlangıç evresi, 2.340'ı büyüme evresi ve 2.005 'i diğer evrelerde olmak üzere toplam 33.430 melek yatırım anlaşmasına yaklaşık 6,8 milyar \$'lık yatırım yapılmıştır (Galveias, 2014: 4).

\section{Grafik 6: Yıllara Göre Melek Yatırımcı Ağı (BAN) Sayısı}

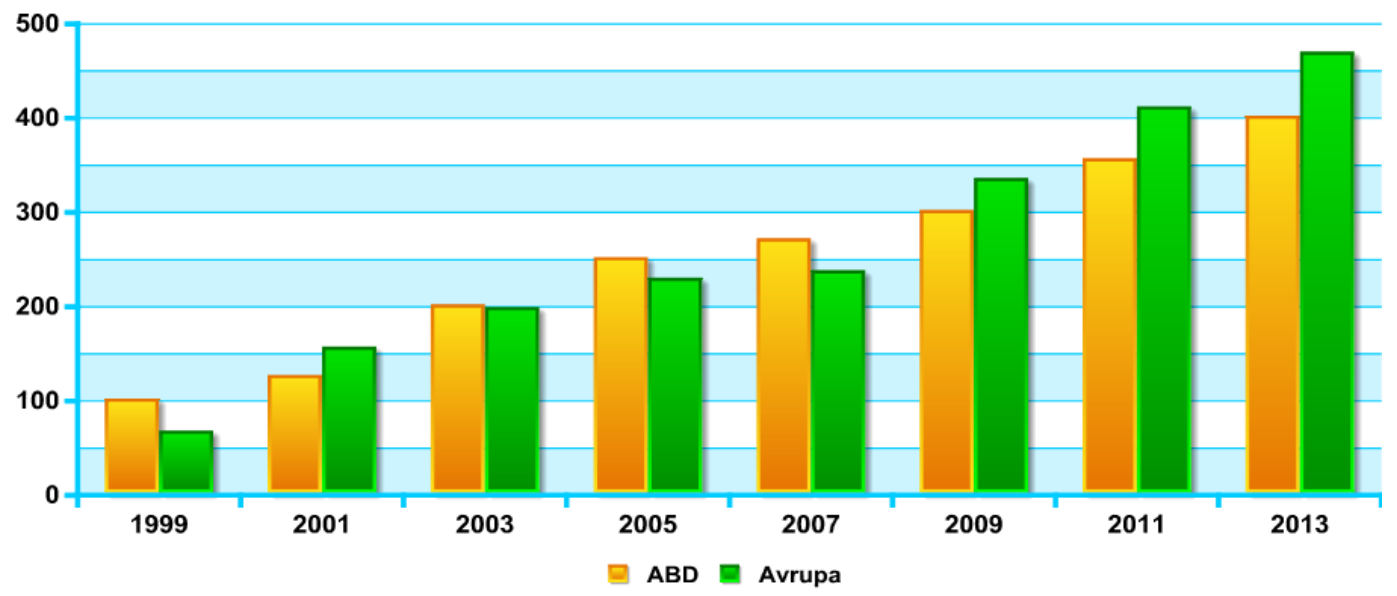

Kaynak: EBAN ve ACA 2013 Raporları

Grafik 6'da melek yatırım ağları sayısı bakımından ABD-Avrupa karşılaştırması yapılmış olup yıllar itibariyle melek yatırım ağları açısından bir artış eğilimi olduğu görülmüş̧ür. Grafiğe bakıldığında Avrupa melek yatırım ağı sayısının 2007 yılından sonra ABD melek yatırım ağı sayısının üzerine çıktığ 1 ve bu eğilimin günümüze kadar devam ettiği görülmektedir. Buradan da anlaşılabileceği gibi 2008 finansal krizi sonrası Avrupa geçte olsa melek yatırımın önemini kavramış ve bu konuda ciddi adımlar atmıştır. Melek yatırımcıların 2013 yılı 
itibari ile ağırlıklı olarak tercih ettikleri sektörler, internet, sağlık hizmetleri, mobil uygulamalar ve yazılım olmuştur. Anlaşma başına yatırım ABD'de 265 bin \$ iken Avrupa'da bu rakam yaklaşık 204 bin \$ seviyesinde gerçekleşmiştir. Türkiye'de ise bu rakam yaklaşık 127 bin \$ seviyesindedir (EBAN, 2012; Hazine Müsteşarlığı, 2013; Hazine Müsteşarlığı, 2014).

Türkiye'de ise melek yatırım anlaşma sayısı tam olarak bilinmemekle birlikte 258'i Hazine Müsteşarllğınca akredite olmuş toplam 750 dolaylarında bireysel melek yatırımcısı tarafından yaklaşık 18,4 milyon \$'lık yatırım gerçekleşmiştir. Bununla birlikte EBAN 2013 raporunda melek yatırım sektörü \%116'lık büyüme oranı ile en hızlı büyüyen ülke olan Türkiye ayrıca BNP Paribas tarafindan yayımlanan Global Girişimcilik Raporu'nda da melek yatırım açısından en cazip üç ülkeler içerisinde gösterilmiştir. Melek yatırım ağları performansı bakımından ise EBAN'ın 2013 yılı sonunda yaptığı çalışmada Türkiye'nin Avrupa ortalamasının üzerinde olduğu belirtilmiştir. Aynı çalışmaya göre Türkiye'de melek yatırım tutarının Gayri Safi Milli Hasıla'ya oranı ise Avrupa ortalamasının altında kalmıştır.

Türkiye'de 2013 yılı sonrasında çıkarılan yönetmelik gereğince kayda alınan melek yatırım sektörü, devlet tarafından teşvik edilmiştir. Bu kapsamda devlet girişimlere yönelik melek yatırımda bulunan yatırımcılara \%75 ile bazı durumlarda \%100 olmak üzere vergi muafiyeti uygulamakta olup, dünya genelindeki vergi teşvikleri bakımından uygulanan teşvik oranı ilk sırayı almakta ve bu da Türkiye'nin melek yatırımcılar açısından cazipliğini arttırmaktadır. 2015 yılı Mayıs ayı itibariyle yayımlanan BKS İlerleme raporuna göre Türkiye'de akredite edilmiş $308 \mathrm{BKS}$ ve $11 \mathrm{BKY}$ ağı bulunmaktadır. Akredite edilmiş BKY'ler \%53'ü yazılım ve uygulama geliştirme, \%40'1 e-ticaret ve \%7'si Bilimsel araştırma ve geliştirme faaliyetleri olmak üzere toplamda 16 anlaşmaya 5,1 milyon TL kaynak aktarmışlardır.

\section{3. İslam Bankacılı̆̆ı}

İslami finans sistemi bir asırlık geçmişe sahiptir. Müslümanların üretken faaliyetleri ve tüketici ihtiyaçlarının finansmanı için oluşturulan sistem İslam medeniyetinin en parlak döneminde ve sonrasında yüzyıllar boyunca oldukça etkili olarak çalışmıştır. Ancak ekonominin merkezi ağırlıklı olarak batı dünyasına kaydığından, yüzyıllar boyunca batılı finansal kurumlar baskın olmuştur ve İslami gelenek pasif şekilde kalmıştır (Iqbal ve Llewellyn, 2002: 1). Son yıllarda ise özellikle de 2008 küresel krizinden sonra İslami finans büyük önem kazanmıştır.

İslam Bankacılığı modeli temelde, fon fazlası olan ekonomik birimlerden fon talebi olan ekonomik birimlere finansal kaynakların faiz olmaksızın aktarılması esasına dayanmaktadır. Aracılık hizmetinde bulunan tüzel kişilik; tasarruf sahiplerinden toplanan kaynakları kar/zarar esasına göre işletmekte ve emeğini ve/veya sermayesini katmaktadır (Özgür, 2007: 11). 
Küresel finans sisteminde küçük ama giderek büyüyen bir paya sahip olan İslam Bankacılı̆̆ sisteminin, son dönemlerde İslam ülkelerinin yanı sira finans piyasalarının gelişmiş olduğu dünyanın çeşitli ülkelerinde de, alternatif bir model olarak kullanımı giderek yaygınlaşmaktadır (Parlakkaya ve Çürük, 2011: 397). Dünya İslami Bankacılık sektörünün 1995 yılı sonunda 140 milyar \$ olan toplam aktif büyüklüğü 2013 yılı sonunda 1,7 trilyon \$'a ulaşmıştır (www.tkbb.org.tr).

Grafik 7: Dünya'da İslam Bankacılığı Sektör Payları

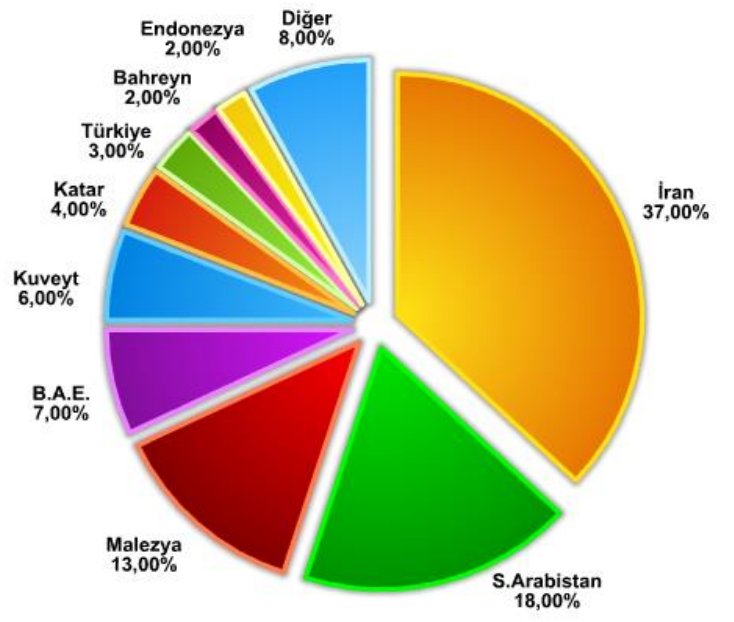

Kaynak: Türkiye Katılım Bankaları Birliği (TKBB)

Türkiye'de İslam Bankacılığı kapsamında ilk örnekler 1983 yılında “Özel Finans Kurumları" adıyla kurulmuş olup 5411 sayılı Bankacılık Kanunu ile özel finans kurumları 2006 yılında "katılım bankası" adını almıştır. Katılım bankacılığı, dini inançları dolayısıyla bankalara yatırılmayarak, yurt içinde ve yurt dışında, altın, döviz ve gayrimenkul olarak tutulan, hatta yastık altında saklanan tasarrufların üretim sürecine dahil edilmesi amaciyla kurulan ve kar-zarar ortaklığı şeklinde faaliyette bulunan kurumlardır şeklinde tanımlanmaktadır (Özdemir ve Özulucan, 2010: 6).

Katılım bankaları 2013 yılı sonu itibariyle Türk bankacılık sektörünün bilanço büyüklüğ̈ açısından \% 5,5'ini, kredi (kullandırılan fon) büyüklüğü açısından \% 6,2'sini ve mevduat (toplanan fon) büyüklüğü açısından \% 6,5'ini oluşturmaktadır (www.tkbb.org.tr). Bu oranların toplam içinde büyük bir yer tutmamasına rağmen, hemen her yıl istikrarlı olarak artış gösterdiği göz önünde bulundurulduğunda, katılım bankacılığının ilerleyen yıllarda bankacılık sektöründe ağırlığını artırması muhtemeldir.

Girişimcilerin finansmanı açısından Katılım Bankaları'nın önemine ilişkin bir gösterge, kullandırılan fonların kredi türü yönünden dağılımı ile ilgilidir. Daha önce de ifade edildiği gibi, mevduat bankalarının toplam kredileri içerisinde KOBİ kredilerinin payı (2013 y1lı için \%25,9), kurumsal/ticari kredilerin (2013 
y1lı için \%42,4) ve bireysel kredilerin $(2013$ yılı için \%31,7) daha az iken bu durum katılım bankalarında KOBI'ler lehine farklılık göstermektedir. 2013 yılı sonu itibari ile Katılım Bankaları'nın kullandırdıkları fonlar içerisinde KOBİ kredilerinin payı \%46,4 olarak gerçekleşmiş iken bu oran kurumsal kredilerde $\% 34$ ve bireysel kredilerde ise \%19,6 olarak gerçekleşmiştir. Bu durum KOBİ'ler açısından Katılım Bankacılığı kaynaklarının daha ulaşılabilir olduğu noktasında bir durumu ortaya koymaktadır.

Grafik 8: Türkiye'de Katılım Bankacılığı Sektörü Temel Göstergeleri

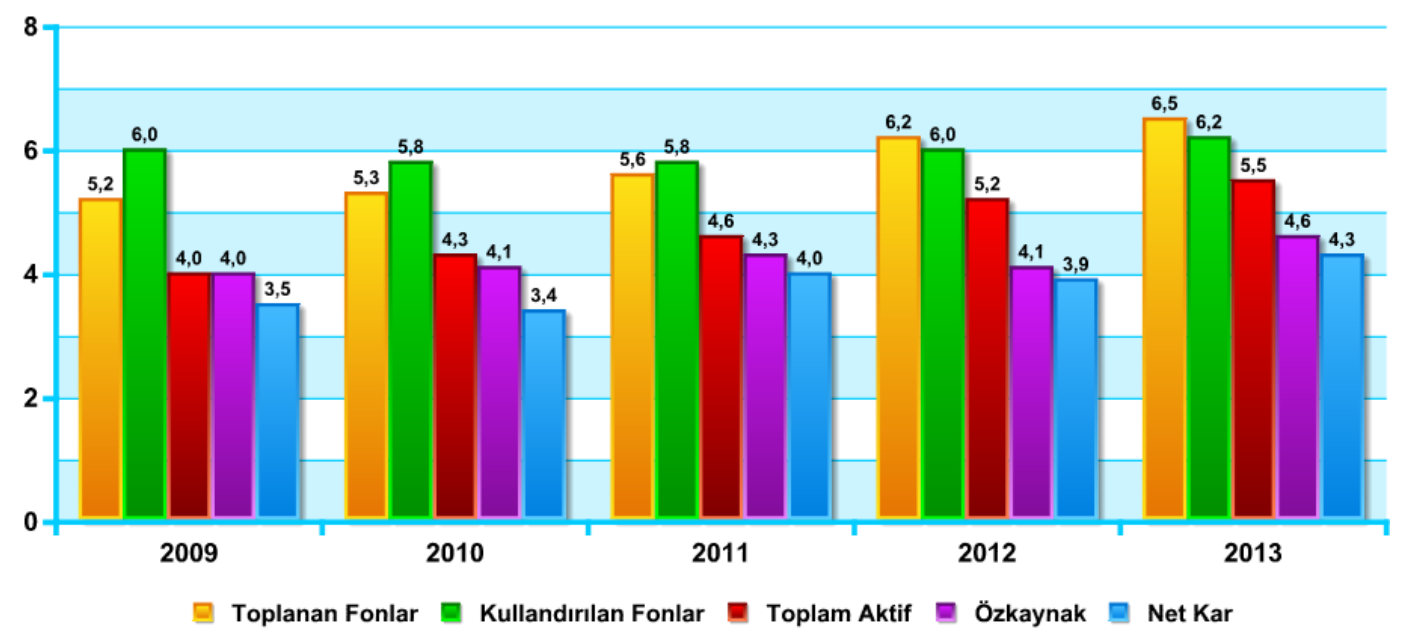

Kaynak: TKBB

Katılım bankaları topladıkları fonları mudaraba, muşaraka, murabaha, şerike ve icare gibi İslam hukukunda yerini bulan ve asırlardır kullanılagelen çeşitli işlemlerle değerlendirmektedirler. Bu işlemler içerisinde katılım bankalarının girişimcilerin finansmanına dönük olarak kullandırdıkları ve birçok kaynakta da belirtildiği üzere girişim sermayesi finansman yöntemi ile büyük ölçüde örtüşen, yine İslam bankacılığı literatüründe, İslam bankalarının vazgeçilmez unsuru olması gerektiği şeklinde değerlendirilen ayrıcalıklı fonksiyon mudaraba sistemidir. Çünkü mudaraba sistemi, kâr/zarar ortaklığı sistemi ile İslami finans sisteminde faiz sisteminin yerine ikame edilen unsurdur. Bununla birlikte kat1lım bankalarının işlemlerinin büyük bir çoğunluğunu murabaha yani ticarette peşin alıp vadeli satma işlemi oluşturmaktadır.

Mudaraba, nakdi sermayelerini değerlendirmek isteyen ancak uzmanlık bilgisi ya da risk iştahı düşük ve "faiz (riba)" kaygısı bulunun bireylerin sermayelerini İslami usullere göre değerlendirmek üzere kurulmuş olan Katılım Bankalarının hizmet stokunda yer alan "faizsiz finansman" seçeneğidir. Türkçeleştirilmiş adıyla "Kar-Zarar ortaklığı” olarak adlandırılmaktadır. 
Mudaraba finansman sistemi, yatırım yapmak için tasarrufu bulunan ve risk-getiri beklentisi piyasa getiri oranından daha yüksek olan yatırımcı ya da aracı bankanın yüksek getiri vaat eden projelere finansman sağlaması ve oluşan gelirden yatırım kararı esnasında anlaşılan oran düzeyinde pay alması ile sonlanan süreçtir.

Burada önemli olan hususlar şunlardır (Kumaş, 2006: 377);

* Yatırımın muhtemel kazancından finansman kaynağının payı kesinlikle oran olarak belirtilmelidir. Belli bir tutar olarak belirlenmesi geleceğin belirsizliği ilkesi ve kar-zarar ortaklığı ilkesine aykırı oluşu dolaysıyla uygunsuz/yanlış olarak değerlendirilmektedir.

* Finanse edilen proje eğer girişimci hatası haricinde sermayede azalmaya(zarar) oluşursa zararın finansmanında girişimcinin sorumluluğu yoktur. Bütün zarar finansman kaynağına aittir. Ancak zararın oluşmasına girişimcinin ihmali sebep oluşturmuşsa zararın tedariği talep edilebilir.

* Eğer finansman kaynağı ve yeni girişimin aynı sektörde yatırımları mevcutsa finansman kaynağının girişimciye alan sınırı koyabildiği “ Kapalı Mudaraba “ sistemi de mevcuttur.

* Girişimin yapılacağı sektörün İslami kurallarla çelişmemesi gerekmektedir.

Ancak Türkiye'de kaynakların kullanımı noktasında dünyadaki benzer uygulamalara göre eksik bir nokta mevcuttur. Türkiye'de katılım bankalarının toplam aktifleri içerisinde mudaraba yatırımlarının payı \%1 bile değildir, ancak bu oran dünyada \%3,9 olarak gerçekleşmektedir (Thomson Reuters Zawya, 2013: 24). $\mathrm{Bu}$ durum, girişimcilerin finansmanı açısından Katılım Bankaları'nın Türkiye'de, İslam Bankaları'nın ise dünyada önemli bir alternatif olmalarına rağmen bu sorumluluklarını yeterince yerine getirmediklerini göstermektedir. $\mathrm{Bu}$ anlamda mudaraba finansmanı, girişimcilerin finansmanı açısından üzerinde çalışılması gereken bir konudur.

Günümüz mevduat bankaları, kalkınma hedefine yönelik uzun süreli yatırım kredileri yerine ticari amaçlı kısa süreli kredilere yönelmekte; bu tutum, gelişmekte olan ülkelerin kalkınmalarına bir engel oluşturmaktadır. İslam Bankaları, kalkınma amacına yönelik yatırım projelerini finanse ederek gelişmekte olan ülkelerdeki bir eksikliği giderebileceği düşünülmektedir. $\mathrm{Bu}$ açıdan bakıldığında ise katılım bankalarının girişim projelerini finanse etmek suretiyle tasarrufların değerlendirilmesine imkân sağlayacak mudaraba sistemine ağırlık vererek, hem kâr/zarar ortaklığının en muteber şeklinin uygulama alanını genişletmesi ve hem de faizsiz bankacılığın kuruluş felsefesinde var olan ekonomik kalkınmaya katkı sağlaması önem arz etmektedir.

\subsection{Mikrofinansman}

Mikrofinansman, yoksul ve düşük gelir düzeyindeki kişi, aile ve mikro işletmelere sağlanan finansal hizmetlerdir. İş yapma fikri olup, gelir getirici bir faaliyette bulunmak üzere, küçük bir başlangıç sermayesine ihtiyacı olan yoksullara imkan sağlamak amacıyla geliştirilen bir finansal destek yöntemidir. Bir mikro 
finansman kuruluşunca bir mikro girişimciye, işini geliştirmesi amacıyla verilmiş olan finansal destek ise mikrokredi olarak ifade edilmektedir. Mikro kredi genellikle işletme sermayesi ihtiyacının karşılanması, hammadde ve malzeme alımı, imalat için gerekli sabit teçhizatın alımı gibi amaçlarla verilmektedir (Dündar, 2007: 2). Bunun dişında geleneksel kredi, mevduat, sigorta ve geçerli mali sistem dişında kalanlara veya bu kuruluşlara ulaşamayanlara yapılan tasarruf, sigorta ve para transferi gibi hizmetler de mikro finansman hizmetleri arasinda sayılmaktadır (Dündar, 2007: 2).

Mikrofinansman gelişmekte olan ülkelerde fakirliğin azaltılmasında önemli bir araç haline gelmiş bulunmaktadır. Geleneksel olarak mikrofinansın fon kaynakları, kamu ve özel sektör bağışları ile kâr amaçlı olmayan yardım kuruluşlar tarafından sağlanmıştır. Ancak son yıllarda mikrofinansın fon kaynakları içinde kâr amaçlı olmayan kuruluşların ve yatırımcıların payı azalmaktadır. Buna karşın daha çeşitlenmiş fon kaynakları ortaya çıkmaktadır. Mikrofinansman, 2000'li yıllarla birlikte ticari bir alan haline dönüşmüş ve ticarileşme hızlı bir şekilde atmaktadır. Ulusal ve uluslararası ticari bankalar sadece gelişmekte olan ülkelerde değil, gelişmiş ülkelerde de artan bir şekilde mikrofinansman kuruluşlarına ilgi göstermektedirler (Krauss ve Walter, 2009: $88)$.

Mikrofinansın ticarileşmesi ile birlikte mikrofinansman kuruluşları geleneksel hizmet alanlarını genişletmişlerdir. Geçmişte kadınlara ve fakirlere küçük miktarlı kredi şeklinde mikrokredi sağlama üzerine odaklanmış bu kuruluşlar günümüzde mikrokrediden mikrofinansmana doğru bir gelişim göstermiştir. Artık mikrofinansman, sadece kadınlara ve fakirlere düşük miktarlı krediler sağlayan mikrokredi kuruluşlarının oluşturduğu bir alan değildir. Mikrokrediden daha geniş bir kapsama işaret eden mikrofinansman, küçük girişimcilere, işletmelere bir takım destekleyici hizmetlerle birlikte fon aktaran bir finansal kaynak türüdür.

Türkiye'de mikro finans hizmetlerine olan talep, mikro ve küçük işletmeler ile yoksul ve az gelirli hane halkları açısından değerlendirilmektedir. Mikro ve küçük işletmeler, faaliyetlerini sürdürmek ya da geliştirmek için, yoksul ve az gelirli kişiler ise iş kurmak ya da tüketim ve diğer ihtiyaçlarını karşılamak için mikro finans hizmetlerini talep etmektedirler. Bu durumda, formel ve enformel sektör girişimcileri, tarım sektörü ve hane halkları mikro finans hizmetlerini talep eden kesimler olacaktır (Gökyay, 2008: 98).

Türkiye'de dünyadaki mikrofinansman uygulamalarına paralel olarak yakın tarihe kadar çok fazla çalışmaların olmadığı görülmektedir. Bununla birlikte mikrofinans hizmetleri bağlamında değerlendirilebilecek ilk uygulamalar para vakıfları olarak karşımıza çıkmaktadır. Para vakıfları, alışılmışın dışında, hayırsever bir kişinin gayrimenkul malını değil de parasını vakfetmesiyle gerçekleşen bir vakıf türüdür. Vakfedilen bu paranın bir daha geri alınması söz konusu değildir. Çizakça (1993)'ya göre burada esas olan paranın mütevelliler 
tarafından işletilmesi ve elde edilen kârın vakfın kuruluş amacına yönelik olarak harcanmasidir.

Bağış yapan vakıfların mutlak mülkiyetinde olan nakit paradan oluşan vakfin sermayesi borç almak isteyen ihtiyaç sahibi insanlara aktarılmakta ve ardından onlar da belirli bir süre sonunda vakfa anapara ile birlikte fazladan bir miktar parayı ödemekteydi. Alınan bu fazla para ise dini ve sosyal amaçlar için kullanılıyordu. Çizakça (1999)'ya göre sağlığın, eğitimin ve refahın büyük oranda bağışlarla finanse edildiği bir toplumda, para vakıfları toplum düzeninin ayakta kalmasında çok önemli bir etkendi. Bununla birlikte faaliyette bulundukları şehirlerin ekonomilerine büyük miktarlarda sermaye girdisi sağlıyorlardı.

Konvansiyonel anlamda ilk mikrofinansman girişimi ise 2002 yllında, bir sivil toplum örgütü olan Kadın Emeğini Destekleme Vakfı tarafından kurulan Maya Mikroekonomik Destek İşletmesi'dir. Türkiye İsrafı Önleme Vakfı, Diyarbakır Valiliği ve Prof.Dr. Muhammet Yunus'un ${ }^{4}$ başkanlığını yaptığı Grameen Trust işbirliği ile Diyarbakır'da 2003 yılında Türkiye Grameen Mikrokredi Projesi (TGMP) adı altında başlatılan proje ile ilk mikrokredi çekleri verilmiştir. TGMP'nin amac1, yoksulun yoksulu olarak nitelendirilen insanlara, özellikle kadınlara, gelir getirici faaliyetlerde bulunmaları için kendi işlerini kurmalarına yönelik küçük kredilerin sunulması olarak belirlenmiştir. Bu proje ile diğer taraftan, yoksulların küçük birer işletme sahibi olmaları sağlanarak yoksulluğun ortadan kaldırılması hedeflenmiştir. Söz konusu proje günümüz itibari ile 67 ilde ve 111 şube ile devam etmektedir. Proje kapsamında 435.376.900 TL kredi dağıtılmıştır. 2015 Temmuz ayı itibari ile 52.232'si kredi alan ve 12.046'sı kredi bekleyen olmak üzere toplam 64.278 üyeye ulaşılmıştır. TGMP kapsamında verilen kredilerin uygulama alanlarına göre dağılımı ise Grafik 9'da görülmektedir.

Türkiye'de mikrokredi ile ilgili diğer önemli uygulama ise İl Özel İdaresi uygulamalarıdır. TGMP projesi ile Diyarbakır'da elde edilen başarıların ardından, 2005 tarih ve 5302 sayılı İl Özel İdaresi Kanunu'nun 6. maddesi ile getirilen düzenleme sonucunda yoksullara mikro kredi verilmesi İl Özel İdareleri’nin görev alanları içerisine alınmıştır.

\footnotetext{
${ }^{4}$ Mikrokredi kavramını bulan ve geliştiren ve aynı zamanda Grameen Bankası'nın kurucusu olan Bangladeşli bankacı ve ekonomi profesörüdür. Sosyal ve ekonomik bir gelişme yaratmadaki çabalarından ötürü 2006 yılında Nobel Barış Ödülü’ne layık görülmüştür.
} 
Grafik 9: TGMP Kapsamında Verilen Kredilerin Dağılımı

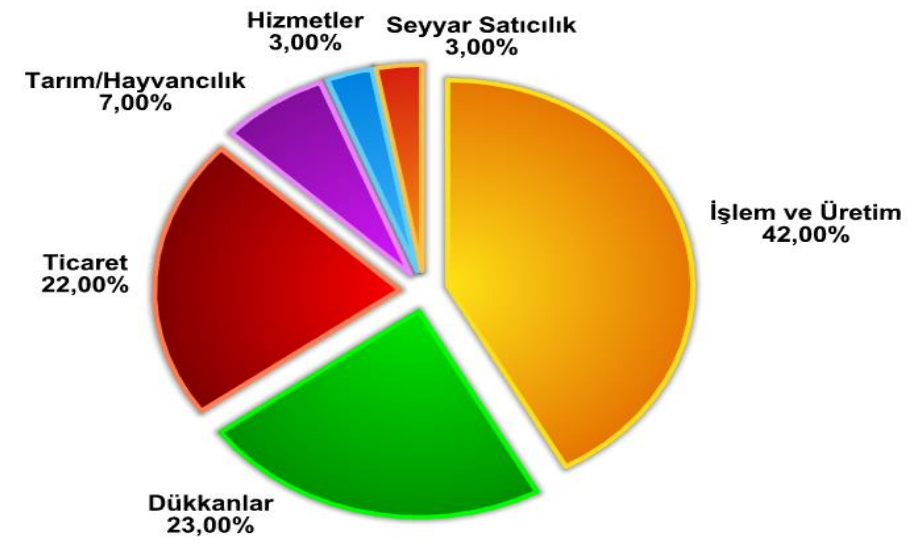

Kaynak: http://www.tgmp.net/tr/

Mikrofinansman veya mikrokredi uygulamaları, girişim sermayesinde birçok yönü ile farklılık göstermesine karşın, özellikle yoksulluğun daha fazla olduğu kırsal bölgelerdeki insanların iş sahibi olmalarını destekleyecek bir uygulama olması nedeniyle bölgesel anlamda organize edilecek girişim sermayesi organizasyonlarını destekleyecek bir mekanizma olarak değerlendirilebilir.

\section{Sonuç Yerine: Girişimciliğin Finansmanında Mevcut Durum Üzerine Öneriler}

Girişimciliğin finansmanında alternatif yöntemler üzerine genel açıklamalardan sonra, söz konusu yöntemlerin geliştirilmesi ve daha yaygın kullanımı üzerine şu genel tespit ve önerilerde bulunulabilir.

Melek yatırımın başarısı, yüksek girişimci potansiyeline sahip olmaktan geçmektedir. Araştırmalar (Hofstede,1980) girişimci ve girişimcilik karakteristik farklılıklarının toplum kültürü ile paralel olduğunu göstermiştir. Bu araştırmalarda bazı kültür yapılarının diğer kültür yapılarına göre girişimciliğe daha yatkın olduğu belirlenmiştir. Kuvan (2007) yapmış olduğu çalışmasında Türk insanının; geleneklerine bağlı, toplumsal davranış kurallarını benimsemiş ve içine kapanık karakteristik özelliklerini taşıdığını vurgulamıştır. Bu özellikler sonucu Türk insanın ortaklık yapısından ziyade bireysel iş sahipliğini benimsediği görülmüş̧ür. Ayrıca BNP Paribas'ın raporunda Türk girişimcilerin in \%78'inin girişimcilik üzerine aile geçmişi bulunan kişilerden oluştuğu ifade edilmektedir. Bu durumun temel nedenleri olarak Türkiye eğitim sisteminde gençlerin; memur olarak, kendisine sunulan seçeneklerde seçim yapıp, kendi seçeneğini oluşturamayan, en büyük hayali iyi ücret veren bir yerde çalışmak olan, yapacağı işi bilmeyip, verilecek işe ve talimata hazır olan bireyler olarak yetiştirilmesi ifade edilebilir. Bundan dolayıdır ki Türkiye 17. büyük ekonomi olmasına rağmen girişimcilik siralamasinda 41. ve rekabet endeksinde 68 . sirada yer almaktadır.

Melek yatırım faaliyetlerini arttırmak ve yeni fikirler oluşabilmesi adına ar-ge çalışmalarına düşen pay büyüktür. Ancak ar-ge yatırımlarına harcanan paranın 
gayri safi milli hasılaya oranı Avrupa'da \%3,3 iken Türkiye'de bu oran sadece $\% 0,95$ seviyelerindedir.

Yapılan araştırmalara (Bektaş ve Köseoğlu, 2007, Kuvan, 2007, İşcan ve Kaygın, 2011) göre Türk girişimci ve girişimcilik dünyası, girişimcilik üzerine eğitim eksikliği, finansal problemler, teknolojik yetersizlikler, ar-ge çalışmaları üzerinde işgücü ve bilgi eksikliği, bireysel beceri zayıflığı ve psikolojik etmenlerden negatif olarak etkilenirken; girişimcilik üzerine hırslı olma, dinamik nüfus, karar ve risk alma becerileri, yenilikçi oluş ve fırsatların farkına varış gibi etmenlerden olumlu olarak etkilenmektedir. Melek yatırımcıların yatırım kararları sosyal, ekonomik ve kişisel sebeplerden etkilenmektedir. Melek yatırımı başarıya taşıyan ana etmenler; yeni iş fikirlerinin hukuki güvencesi, risk alma davranışları, yenilikçilik ve proaktiflik olarak sıralanabilir.

Dünyada melek yatırımcılara yönelik teşvikler, yönetmelikler bölgesel bazlı uygulanmakta iken Türkiye'de tek bir merkezden uygulanan teşvik ve yönetmelikler mevcuttur. Buda Türkiye'de melek yatırım aktivitelerinin genellikle büyük şehirler etrafında yoğunlaşması sonucunu doğurmuştur.

Tüm bu eksikliklere rağmen Türkiye'de melek yatırımcı profilinin BNP Paribas'ın Global Girişimcilik Raporu'nda melek yatırımı \% 77'lik oranla az riskli olarak nitelendirmesi, devletin yüksek oranlı vergi teşvikleri, fikri koruma kanunları, mevcut melek yatırımcıların girişimci odaklı oluşları, ar-ge çalışmalarına aktarılan kaynağın yıllar itibariyle önemli gelişmeler göstermesi, Türkiye'de melek yatırımcı profilinin $\mathrm{ABD}$ ve Avrupa ortalamasının üzerinde olarak servetlerinin \%10,6'l1k kısmını melek yatırım faaliyetlerinde kullanmaları, 2015 itibari ile 1.000 BKY hedefi, 2023 itibari ile \%3'lük ar-ge harcamaları/GSMİ hedefi ve son yıllarda yayımlanan raporlarda Türkiye'nin melek yatırım açışından cazip olarak gösterilmesi bu hususta ilerleme kaydedildiğini göstermekle birlikte, gelişmiş ülkelerin çok gerisinde olunduğu unutulmamalıdır.

$\mathrm{Bu}$ çalışma sonucunda melek yatırım ve girişim sermayesi faaliyetlerinin ve başarının arttırılması için şu önerilerde bulunulabilir;

* Gelişmiş ülkelerle kıyaslanabilir bir seviyeye ulaşmak amacıyla, girişimcilik çevresinin geliştirilmeli ve girişimcilik kültürü tüm toplumu kapsayacak şekilde genişletilmelidir.

* Ülke genelinde, girişimcilik ve melek yatırıma yönelik eğitim ve danışmanlık hizmetleri yaygınlaştırılmalıdır.

* Girişimcilik dersi eğitim müfredatına 4 ve 5. sınıflarda eklenmeli ve gençlerimiz girişimcilik kültürüne sahip bireyler olarak küçük yaştan itibaren yetiştirilmelidir.

* Girişimcilik ve melek yatırım üzerine; yarışmalar, ödüller ve teşvikler, üniversite tanıtım etkinlikleri gibi ülke çapında destekleyici aktiviteler yürütülmelidir.

* "Girişimcilik Konseyi” gibi yapılar oluşturarak girişimciler ve melek yatırım organizasyonları arasındaki koordinasyon sağlanmalıdır. 
* Girişimcilik ve melek yatırım üzerine her bölgede iş dünyası, üniversiteler ve araştırmacılar tarafından ortak etkinlikler yürütülmelidir.

* Ar-ge çalışmaları arttırılmalı ve yapılan ar-ge çalışmaları sonucu yeni fikir ve ürünlerin ortaya konulabilirliği arttırılmalıdır.

* Bireysel ve melek yatırımcı ağı bazında mevcut melek yatırımcıların bölgesel bazda ofisler açarak, girişim ve yeni iş fikirlerine kaynağında ulaşması teşvik edilmelidir.

* Melek yatırıma ait teşvik ve yönetmelikler bölgesel bazda ele alınarak, sosyokültürel ve sosyo-ekonomik farklılıklar göz önüne alınarak yeni teşvik ve yönetmelikler hayata geçirilmelidir.

Girişim sermayesi ve melek yatırım gibi, hali hazırdaki girişim finansman kaynakları incelendiği takdirde uzmanlık alanı olarak tamamen yeni iș fikirlerinin, girişimlerin incelenmesini belirledikleri görülmektedir. Ancak Katılım Bankaları tarafından kullandırılan ve girişimciliğin finansmanı açısından önemli bir alternatif olma potansiyeline sahip olan mudaraba sisteminin uygulanmasi bu noktada aksaklık yaşamaktadır. Mudaraba sistemi yalnızca katılım bankaları tarafından kullanılabilmektedir. Her ne kadar katılım bankası olsalar da bankalar topladıkları fonları kredi olarak kullandırma genel sistemi ile çalışmaktadır. Kredi kullandırılan kurumların seçiminde finansal tablo analizine büyük ağırlık verilmektedir. Ne var ki yeni girişimin doğası gereği, finansmana ihtiyaç duyan girişimler yeterli faaliyet geçmişine sahip olmadıklarından dolayı geleneksel kredilendirme sürecinin dişında kalmaktadırlar. $\mathrm{Bu}$ noktada fon talep eden girişimlerin değerlendirilmesi ayrı bir uzmanlık bilgisi gerektirmektedir.

Katılım bankalarının başka finansman yöntemlerini de kullanabiliyor olması ve hâlihazırda konvansiyonel banklarla rekabet etmek zorunda oluşları onları yüksek risk içeren yeni girişimlerin finansmanından uzak tutmaktadır. Ayrıca Türkiye'de kâr payı oranlarının nispeten yüksek oluşu bankalara beklentileri oranında kar sağlamada kolaylık sağlamaktadır. Kar arzusunu normal fonlama yöntemleriyle sağlayan bankalar ise yüksek riskli ürünleri portföylerine katmayı değerlendirmemektedir.

Bu bağlamda, mudaraba finansman yönteminin Katılım Bankaları tarafından daha yaygın kullanılması ve böylece girişimcilerin finansmanı açısından önemli bir alternatif haline gelebilmesi için yapılması katkı sağlayacak uygulama önerileri şu şekilde ifade edilebilir;

* Katılım Bankaları'na mudaraba sistemi ile kullandıracakları fonlardan elde edecekleri gelirlerine kısmen ya da tamamen vergi muafiyeti uygulanmalıdir. Bankaların arz fazlası oluşturması teşvik edilmelidir.

* Katılım Bankaları'nın mudaraba sisteminin tanıtımına yatırım yapması gereklidir. Ya da yeni bir isim ile ürün yeniliği kapsamında yeni ama mudaraba temelli bir hizmet seçeneği oluşturmalıdır. $\mathrm{Bu}$ sistemin modernizasyonuna katkı sağlayacaktır. Yapılacak yeniliğin, proje finansörleri 
olan banka müşterilerinin hak dağıtımı ve bilgi asimetrisi alanında yapılması faydalı olacaktır.

* Katılım Bankaları'nın sigortacılık alanında sağladıkları ortak çalışmayı mudaraba alanında sağlaması teşvik edilmelidir. Mevcut girişim sermayesi şirketleri fon olarak oldukça güçlüdür, ancak bir ortaklık çatısı altında bu şirkeler ile rekabet etmek mümkündür. Nitekim bu ortak çalışma alanında uzman insan kaynaklarının tedarik ve eğitimine imkân sağlaması kaçınılmazdır. Bu sayede katılım bankaları mevcut en büyük problemleri olan değerlendirme problemlerini aşacaktır.

* Katılım Bankaları'nın proje finansmanı konusunda muhtemel rakipleri olan GSYO'lar finanse ettikleri projelere danışmanlık hizmeti de sunmaktadırlar. $\mathrm{Bu}$ bağlamda bankaların organizasyon yapısı bankalardan farklı olan bir sistem kurması kaçınılmazdır. Yeni oluşturulacak olan organizasyonun banka algısı yıkılmalıdır. Nitekim bankalar toplumumuzda borç veren organizasyonlar olarak değerlendirilmektedir. $\mathrm{Bu}$ da yatırımcı tarafinda hoş karşılanması beklenen bir algı değildir.

* Katılım Bankaları'nın mudaraba fonu sağladıkları şirketlerin belli bir dönem vergiden muaf tutulması ile bankaların raporlama noktasındaki isteklerine, girişimcilerin vergi maliyeti kaygısı ortadan kalktığı için daha doğru şekilde yanıt vermeleri sağlanabilir.

* Katılım Bankaları GSYO’lara göre oldukça fazla sayıda şubeye sahiptir. Bu da mobilite imkânı sağlamaktadır. Devlet tarafından sağlanacak teşvikler ile Katılım Bankları'nın yüksek şube sayısı sayesinde girişim sermayesi finansmanının yurdun bütün noktalarına yayılması kolaylaşabilecektir.

* Türkiye'de mevcut olan veri eksikliği ve düzensiz dokümantasyon nedeniyle merkezden sağlanan hibelerin Katılım Bankaları aracılığı ile finanse edilen projelerin bir kısmına hibe olarak verilmesi düşünülebilir. Devlet-bankagirişimci arasında bir çeşit kazan-kazan sistemi uygulanabilir. Bu uygulama hem fon mobilitesini artırıp Katılım Bankaları'nın riskini azaltacak, hem de etkinlik noktasında gerekli denetim ve veri toplama sürecinin özel sektör tarafından yapılmasını sağlayacaktır.

* Katılım bankaları hali hazırda banka olan kuruluşlardır. Dolaysıyla fonları genellikle kısa vadeli olarak toplayabilmektedirler. Ancak ar-ge projeleri ya da geri dönüş süresi uzun olan yeni girişim projeleri finanse edileceği için yeni vade-ürün planları oluşturmaları gerekmektedir.

Girişim ve girişimciliğin finansmanında kullanılan ve kullanım potansiyeli bulunan alternatif finansman yöntemlerin daha etkin ve yaygın şekilde kullanımına yönelik ifade edilen bu öneriler ve yeni öneriler konusunda akademiada bir farkındalık oluşturulması ve bu konunun çalıștay ve sempozyumlarda da yaygın şekilde tartışılması önemli bir katkı sağlayacaktır. 


\section{Kaynakça}

Bektaş, Ç. ve Köseoğlu, M.A. (2007), "Etik Kodların Yönetsel Karar Alma Sürecine Etkileri ve Bir Model Önerisi", "İş, Güç” Endüstri İlişkileri ve İnsan Kaynakları Dergisi, 9(2), 94-115.

BNP Paribas (2015), "Global Entreprenurialism Report", https://wealthmanagement. bnpparibas.com/public/en/achieving-your-goalsentrepreneur-report (Erişim: 18.03.2015).

Çizakça M. (1993), Risk Sermayesi, Özel Finans Kurumları ve Para Vakıfları, İslami İlimler Araştırma Vakfi, No: 8.

Çizakça M. (1999), İslam Dünyasında ve Batı'da İş Ortaklıkları Tarihi, Tarih Vakfı Yurt Yayınları, No: 75.

Demirel, E. T, Tikici M. (2004), "Kültürün Girişimciliğe Etkileri”, Fırat Üniversitesi Doğu Anadolu Bölgesi Araştırmaları Dergisi, 2(3), 49-58.

Dündar, S.O. (2007), Mikrofinansman, Türkiye Kalkınma Bankası A.Ş., Ekonomik ve Sosyal Araştırmalar Müdürlüğü.

EBAN (2012), European Angel Investment Overview.

Galveias L. (2014), Overview of European Statistics for 2013, EBAN Congress.

Gökyay, Ç. (2008), Türkiye'de Mikro Kredi Uygulamaları ve İstihdama Yansımaları, Çalışma ve Sosyal Güvenlik Bakanlığı, Uzmanlık Tezi, Türkiye İş Kurumu Genel Müdürlügü.

Hazine Müsteşarlığı (2013), Bireysel Katılım Sermayesi Hakkında Yönetmelik, Resmi Gazete, Sayı 28560.

Hazine Müsteşarlığı (2014), "Bireysel Katılım Sermayesi İlerleme Raporu", https://www.hazine.gov.tr/File/?path=ROOT\%2F1\%2FDocuments\%2FBireysel+ Kat\%C4\%B11\%C4\%B1m+Sermayesi+ve+Kambiyo+Raporlar\%C4\%B1\%2FEYL \%C3\%9CL+2014.pdf (Erişim: 21.01.2015).

Hofstede, G. (1980), Culture's Consequences: International Differences in Work-Related Values. Beverly Hills.

http://www.angelcapitalassociation.org/data/Documents/Resources/ACAAngelBackground 2014.pdf (Erişim: 16.04.2015).

http://www.eban.org/wp-content/uploads/2013/07/EBAN-Angel-InvestmentOverview-2012.pdf (Erişim: 01.04.2015).

http://ebancongress2014.org/downloads/presentations/09.30\%20luis\%20EBA N\%20Statistics\%202014\%20-\%20Congress.pdf (Erişim: 07.03.2015).

http://www.oecd.org/industry/smes/33705673.pdf (Erişim: 22.02.2015). 
https://www.hazine.gov.tr/tr-TR/Rapor-Sunum-

Sayfasi?mid=250\&cid=30\&nm= 45\# (Erişim: 19.02.2015).

http://www.kap.gov.tr/sirketler/islem-goren-sirketler/sektorler.aspx (Erişim: 27.03.2015).

http://www.resmigazete.gov.tr/eskiler/2013/02/20130215-2.htm (Erişim: 30.03.2015).

http://www.spk.gov.tr/apps/kyd/iletisim.aspx?ctype=rsyo\&submenuheader=1 (Erişim: 03.01.2015).

http://www.tkbb.org.tr/ (Erişim: 03.01.2015).

http://www.yoikk.gov.tr/upload/komiteler/kobi/gsyo.pdf

(Erişim: 11.02.2015).

Iqbal, M., ve Llewellyn, D.T. (2002), Islamic Banking and Finance: New Perspectives on Profit-Sharing and Risk, Edward Elgar Publishing, Inc.

İbicioğlu, H., Taş, S. ve Özmen, H.İ. (2010), "Üniversite Eğitiminin Girişimcilik Düşüncesinin Değişimine Etkisi: Üniversite Öğrencileri Üzerine Bir Uygulama”, Alanya İsletme Fakültesi Dergisi, 2(1), 53-74.

İşcan, Ö. ve Kaygın, F. (2011), "Potansiyel Girişimciler Olarak Üniversite Öğrencilerinin Girişimcilik Eğilimlerini Belirlemeye Yönelik Bir Araştırma", Organizasyon ve Yönetim Bilimleri Dergisi, 2, 275-286.

Kalkınma Bakanlığı (2014), “Onuncu Kalkınma Planı (2014-2018): Girişimciliğin

Geliştirilmesi",http://www.kalkinma.gov.tr/Lists/zel\%20htisas\%20Komisyonu\%2 0Raporlar/Attachments/242/giri\%C5\%9Fimcili\%C4\%9Fin\%20geli\%C5\%9Ftiril mesi\%20OIK\%C4\%B1.pdf (Erişim: 16.04.2015).

Kao, R.W.Y. (1993), "Defining Entrepreneurship: Past, Present and?", Creativity and Innovation Management, 2(1), 69-70.

Karabayır, M.E. ve diğerleri. (2012), "Melek Yatırımcıların Yatırım Kararlarında Girişimci Odaklılığın Rolü: Türkiye'deki Melek Yatırımcılar Üzerine Bir Çalışma”, Ankara Üniversitesi SBF Dergisi, 67(2), 69-93.

Kızılgöl, Ö. ve İşgüden, B. (2008), "Bandırma ve Norfolk Şehirlerinin Girişimcilik Profillerinin Karşılaştırmalı Analizi Üzerine Bir Araştırma”, Yönetim ve Ekonomi Araştırmaları Dergisi, 9(1), 2-14.

Krauss, N., ve Walter, I. (2009), "Can Microfinance Reduce Portfolio Volatility?" Economic Development and Cultural Change, 1, 85-110.

Kumaş M. S. (2006), "Bir Finansman Yöntemi Olarak İş Ortaklığı Uygulamas1 "Mudârabe-Commenda Karş1laştırması", Uludağ Üniversitesi Illâhiyat Fakültesi Dergisi, 15(1), 370-383. 
Kuvan, H. (2007), Türk Girişimcilerinin Yaşam ve Çalışma Değerleri: Malatyalı Girişimciler Üzerine Bir Araştırma, Süleyman Demirel Üniversitesi, Sosyal Bililer Enstitüsü, Yayınlanmamış Doktora Tezi.

Oduyoye O.O., Adebola S.A. ve Binuyo A.O. (2013), "Business Failure and Performance of Ogun State Cooperative Federation: An Evaluation Approach", Arabian Journal of Business and Management Review (OMAN Chapter), 2(11), 71-79.

OECD, "Financing High Growth Firms: The Role of Angel Investors, OECD Publishing”, http://dx. doi.org/10.1787/9789264118782-en (Erişim: 17.03.2015).

Osnabrugge, M.V. (2002), "A Comparison of Business Angel and Venture Capitalist Investment Procedures: An Agency Theory-Based Analysis", Venture Capital, 2 (2), 91-109.

Özdemir, F.S., ve Özulucan, A. (2010), Katılım Bankacılı̆̆ı, Türkmen Kitabevi.

Özgür, E. (2007), "Katılım Bankalarının Finansal Etkinliği ve Mevduat Bankaları ile Rekabet Edebilirliği”, KSÜ Sosyal Bilimler Dergisi, 4 (1-2), 11-20.

Parlakkaya, R. ve Çürük, S.A. (2011), "Finansal Rasyoların Katılım Bankaları ve Geleneksel Bankalar Arasında Bir Tasnif Aracı Olarak Kullanımı: Türkiye Örneği”, Ege Akademik Baklş, 11(3), 397-405.

Thomson Reuters Zawya (2013), Kuwait Finance House Research (Kuveyt Finans Araştırma), Dünyada İslami Finansal Aktiflerin Dağılımı.

Uluköy, M., Demireli, C. ve Kahya, V. (2013), “KOSGEB Girişimcilik Eğitimi Kurslarına Katılan Katılımcıların Girişimcilik profiline Yönelik Bir Alan Araştırması", Girişimcilik ve Kalkınma Dergisi, 8(2), 79-96.

Yüksel, A. (2011), Türkiye'de KOBİ'lerin Banka Kredilerine Erişimi, DPT Uzmanlık Tezi. 